\title{
Translating Jedi and Sith. Proper names in early translations of Star Wars novels to German, Polish and Russian
}

\author{
Adam Nowakowski \\ Krosno State College \\ adam.e.nowakowski@gmail.com
}

\begin{abstract}
The presented paper argues the importance of proper names in fantasy and science fiction in general, but focuses primarily on the highly successful Star Wars franchise. Worldwide popularity of George Lucas' creation resulted in the need for translation of Star Wars materials to other languages. Translators were given a task, among others, of creating a glossary of proper names essential to the overall story, such as Jedi and Sith. This paper is an analysis of translation of these proper names in Star Wars novels released before the year 2000 in German (61), Polish (41) and Russian (19). It presents all variants proposed by the translators before the final one was canonized and comments on their choices and strategies used. The analysis shows that while German and Polish translators usually retained use of previously established versions, Russian translators proved to be less consistent in this matter.
\end{abstract}

Keywords: proper names, proper names in fantasy, translation of proper names, Star Wars, popular culture.

\section{Streszczenie}

Tłumacząc Jedi i Sithów. Nazwy własne w pierwszych tłumaczeniach powieści z serii Star Wars na język niemiecki, polski i rosyjski

Niniejszy artykut poświęcono istotności nazw własnych $w$ fantastyce na przykładzie amerykańskiej franczyzy Gwiezdne Wojny. Światowa popularność stworzonego przez George'a Lucasa uniwersum zrodziła zapotrzebowanie na thmaczenie towarzyszacych mu materiałów. Jednym z zadań tłumaczy było stworzenie glosariusza nazw własnych kluczowych dla fabuty, wielokrotnie powracajacych, takich jak np. Jedi oraz Sith. Niniejszy artykut stanowi analize ttumaczeń wymienionych nazw własnych $w$ powieściach z serii Gwiezdne Wojny opublikowanych w językach niemieckim (61), polskim (41) i rosyjskim (19) przed 2000 rokiem. Zawiera on wszystkie zaproponowane $w$ nich przez tlumaczy warianty, komentuje ich wybory $i$ wykorzystane strategie. Analiza pokazuje, że podczas gdy tlumacze 
niemieccy i polscy z reguly wykorzystywali zaproponowane wcześniej wersje, o tyle rosyjscy postępowali pod tym względem mniej konsekwentnie.

Słowa kluczowe: nazwy własne, nazwy własne $w$ fantastyce, tlumaczenie nazw wlasnych, Gwiezdne Wojny, kultura popularna.

\section{Realistic fantasy}

Fantasy is commonly seen as the exact opposite of reality. Not only in strictly dictionary terms, but also in regard to film and literature. In eyes of people not well immersed in this genre, fantasy seems to be deprived of logic or rules and entirely separated from our reality. Because of that it famously requires suspension of disbelief from its viewers and readers to be fully appreciated.

This point of view lacks the proper depth to appreciate all that the genre has to offer. It ignores the fact that well-crafted fantasy stories demand a tremendous effort to be put in worldbuilding. These unreal universes, born mostly from pure imagination, require, among others, their own history, geography, political system, mythology, language and - most importantly - a set of rules that are never to be violated. This, in fact, makes them incredibly fragile. A transgression of previously established canon may cause the illusion to break, which will lead the constructed world to collapse in the eyes of a viewer or reader. ${ }^{1}$ Thus a metaphorical agreement between the author and the consumer must be followed.

In other words, fantasy worlds need to be cohesive, internally logical, probable and realistic. Even if the first step to be taken by any viewer or reader of fantasy is to suspend their disbelief enough to accept a world where, for example, magical creatures exists alongside humans.

\section{Constructed world of Star Wars}

As far as fantasy worlds are concerned, Star Wars is undoubtedly one of or even the most successful one (especially in terms of finances and worldwide popularity). I believe that one of the main reasons behind the franchise's prosperity is namely the extraordinary immersiveness of the Star Wars Universe, which successfully combines both strangeness and familiarity. 
Even the first scenes of the George Lucas' original 1977 movie (Star Wars, re-released in 1981 under the title Star Wars: Episode IV-A New Hope) serve as a great example of a highly effective worldbuilding. The viewer is introduced to a desert planet of TATOOINE, inhabited by species such as the nomadic SAND PEOPLE and robe-wearing JAWAS. The latter are scavengers, who sell discarded or abandoned equipment to the local MOISTURE FARMERS such as OwEN LARS and his nephew LUKE SKYWALKER. Viewers first meet them as Jawas park their SANDCRAWLER in front of Lars' homestead in order to present their used wares. Uncle Owen plans to buy an ASTROMECH DROID and a droid fluent in language of MOISTURE VAPORATORS and BoCCE. In such circumstances Skywalker meets RD-D2 and C-3PO, the story's other main protagonists, and thus his "hero's journey” commences.

Everything seen up to this moment - ships, vehicles, machines, robes - is old, dirty, rusty, or even crumbling, which is in accordance with Lucas' vision of his "Used Universe." Its establishment was a unique creative decision, since science fiction or space fantasy movies of that time generally featured perfectly clean and sterile futuristic environments. ${ }^{2}$ Undoubtedly, this visual aesthetic immensely enhances the believability of the world of Star Wars, as it provides the "lived-in" quality. It can be called one of three pillars it was founded on.

The aim of the description above was not only to show the worldbuilding skills of Lucas, but also to highlight the role that language plays in the process (which serves as the second pillar). Language, or to be precise, such its elements as proper names (JAWAS, TATOOINE, BOCCE etc.) and neologisms (MOISTURE VAPORATOR, DROID, SANDCRAWLER etc.) are used to name and identify components of the constructed world that are not familiar to the viewer or reader but are common to its inhabitants.

Joseph Scrimshaw and Ken Napzok (2018: 09:45) made an insightful remark concerning this matter, noticing that in the Star Wars Universe an additional level of name creativity can be observed, as many of its elements possess not only formal names, but also informal ones used in everyday speech. For example, the SAND PEOPLE are also referred to as TUSKEN RAIDERS or simply TUSKENS. The latter is in fact their official name in Basic language (i.e. English, as it is called in the Star Wars Universe). Similarly, in Rian Johnson's The Last Jedi (2017: 01:04:23) it is revealed that the Mega Class Star Destroyer "SupremaCy", the mobile capital of the First Order, is also commonly known as SNOKE's BOUDOIR.

This mechanism strongly contributes to the believability of the constructed world. It is easy to imagine that not all characters would know the established name of every element of the world which he or she inhabits, since we all occasionally struggle with such tasks (for example, when visiting a hardware store). Because of that, to name just few examples, Anakin 
Skywalker in Lucas' The Phantom Menace (1999: 00:41:49) calls Qui-Gon Jinn's LIGHTSABER a LASER SWORD, while Poe Dameron in Johnson's The Last Jedi (2017: 02:13:46) refers to foxlike VULPTICES as CRYSTAL CRITTERS.

Finally, the third pillar that the constructed world of Star Wars was founded on is the "organic" sound. It is credited mostly to the multiple Academy Award winning sound designer Ben Burtt who brought to life Lucas' vision. As it is discussed by Jennifer Landa (2018), Burtt based the soundscape of Star Wars on sounds existing in the real world, thus making them feel organic, familiar and believable. It was an additional surprising creative choice since sound designers working on science fiction movies of the past used primarily electronic sounds in order to create their "otherworldly" environments. However, in Star Wars movies, the speech of Chewbacca the Wookie is based on grunts, moans and roars of bears, lions, badgers, and walruses; R2-D2 the droid communicates his wide palette of feelings with a mixture of synthesizer-generated sounds and Burtt's own voice; the Huttese language is based on Quechuan (natively spoken by the Quechua people, primarily living in the Andes and highlands of South America), while the language of Ewoks was inspired by Kalmyk (spoken by the Kalmyk people in the Republic of Kalmykia - a federal subject of Russia).

\section{Star Wars literature}

Even though Star Wars is a film-centric franchise, it is also well rooted in literature. In fact, the novelization of the first movie (Star Wars: From the Adventures of Luke Skywalker, ghostwritten by Alan Dean Foster under Lucas' name) was published in November of 1976, several months prior to the premiere of Lucas' Star Wars (1977). February of 1978 saw the release of Foster's Splinter of the Mind's Eye, which was the first spin-off novel and a potential sequel to Star Wars, featuring characters from the movie, but embarking on a new adventure. Thus the so called Star Wars Expanded Universe (SWEU) was born ${ }^{3}$ - an extension of the theatrical films, which included all fictional material licensed by Lucasfilm, such as books, comic books, video games, and television series. It contributed to growing the fan community and keeping it intact between the release of Richard Marquand's Return of the Jedi (1983) and Lucas' The Phantom Menace (1999).

By 2013 the official timeline for SWEU novels, which at the time almost 300 had been released, was spanning from 25,793 years before the events of Star Wars to 45 years after, and featured the story of several galactic wars and generations of Skywalkers. However, in 2014, two years after the Disney Corporation's purchase of rights to Star Wars, Lucasfilm announced 
that in preparation for the upcoming sequel trilogy, SWEU would be retconned. It was rebranded as Legends and cast aside, while a new continuity known as Canon was launched. It consisted only of the original six theatrically released films, The Clone Wars television series and film, and all future material from that point onward.

\section{Star Wars novels in translation}

The main goal of the presented paper is to analyze the translation of selected proper names in all SWEU novels, that were published in German, Polish, and Russian before the year 2000. Such limitation is required due to the already overwhelming size of analyzed material. The release of The Phantom Menace in 1999 is a good landmark moment, as it revived the fandom and SWEU by introducing the franchise to a new generation. A great number of novels, comic books, and video games followed soon after.

One can argue that worldwide popularity of the Star Wars franchise was made possible partly because of translations into multiple languages. On the other hand, others may claim that it was the already a popular culture phenomenon that required such impressive translation effort.

In Germany an impressive number of 61 SWEU novels were released between 1978 and 1999 by four publishers: Goldmann (1978-1994), VGS (1994-1999), Heyne (1994-1999) and Blanvalet (1999) ${ }^{4}$. They were translated by Thomas Ziegler (accounted for 13 of them), Heinz Nagel (10), Tony Westermayr (5), Regina Winter (5), Andreas Helweg (4), Ralf Schmitz (4), Manfred Weinland (4), Christoph Göhler (3), Dominik Kühn (3), Thomas Hag (2), Michael Iwoleit (2), Michael Kubiak (2), Hans Sommer (2), Andreas Decker (1), Horst Pukallus (1) and Hans Zwack (1). It is noticeable that all of these novels, including the few from the 1970s and 1980s, were released shortly after their American premieres. Such long presence of the franchise in Germany undoubtedly helped to establish the canon Star Wars glossary early on.

As far as Polish literary market is concerned, 41 SWEU novels were released during the examined period. The first 3 were the novelizations of the Original Trilogy (1977-1983) published by InterArt in 1990-1992. In 1994 publishing rights were transferred to Amber, which re-released the previous books (slightly re-edited) and had been publishing SWEU novels up to $2014^{5}$. Since 1999 Egmont Polska also has been publishing Star Wars materials, but the corporation focuses primarily on comic books. Nevertheless, it has released one novel before the year 2000 - Jedi Apprentice: The Rising Force by Dave Wolverton. 
List of translators who brought SWEU novels to Polish readers consists of such names as Andrzej Syrzycki (19), Jarosław Kotarski (5), Radosław Kot (3), Anna and Jan Mickiewicz (3), Piotr Cholewa (2), Wacław Najdel (2), Jan Woydyga (2), Magdalena Ostrowska (1), Agnieszka Sylwanowicz (1), Maciej Szymański (1), Krzysztof Kurek (1), Krystyna Kwiatkowska (1) and Wojciech Szypuła (1). ${ }^{6}$

Early presence of SWEU novels in the Soviet Union and later in Russia is a complicated topic worthy of a separate paper. The first books to be released were the novelizations of the Original Trilogy. They were published shortly before and after the fall of the Soviet Union. At least ten editions of each novel exist. All were released without a license from Lucasfilm and in different translations (mostly anonymous). ${ }^{7}$ Only in 1996 Azbooka Publishers acquired proper rights and soon the official release of several novels from the Expanded Universe followed. ${ }^{8}$ Overall, 19 novels were released in Russian before the year 2000. The list of identified translators includes: I. Feygin (3), A. Snezhko (3), V. Naydenov (3), V. Kuznetsov (3), A. Chekh (1), A. K.-E. Elizastegi (1), S. Frolyonok (1), E. Gladkova (1), M. Kononov (1), V. Fyedorov and A. Seleznyov (1), G. Padosokorskaya (1), V. Pravosudov and A. Kolomeytsev (1), O. V. Razumovskiy (1), A. Rudoy (1), A. Tokarev (1), A.L. Utkin (1), I. Veselova (1). It is worth noting that the first three on the list were responsible for translating the novelizations of the Original Trilogy, which were all released in one volume. Before the year 2000 Kuznetsov was the only Russian translator who worked on SWEU novels on more than one occasion. ${ }^{9}$

\section{Proper names of Star Wars in translation}

The presented paper is an analysis of proper names commonly associated with Star Wars and widely used in the novels. An extensive list of such could easily be created. Due to the limitation of space, I decided to focus only on JEDI and SITH and their various forms. Overall, it can be argued that the Star Wars franchise is synonymous with JEDI. On the other hand, SITH is basically the antithesis to JEDI.

Translation of proper names is an age-long dilemma for translators and because of this, a set of strategies was developed. Peter Newmark's (1988a, 1988b) work in this field had arguably the biggest impact on translation studies. Bartosz Poluszyński (2012: 45-46) combined translation strategies described by Newmark with proposals of other researchers. As a result he fashioned a list as follows, which I based my analysis on:

- transference,

- substitution, 
- translation,

- modification,

- transcription / transliteration,

- addition,

- translator's note.

Consistency is one of the greatest tasks that await any translator. This is especially true when dealing with a long series of books, written by numerous authors, over an extended period of time, which have already been translated by various translators. A good practice in such scenarios is to create a common glossary, which would include proper names, neologisms, catch phrases, and idioms used in the series that must be translated consistently. In some cases, such glossary is a result of an agreement of cooperating translators. Alternatively, it is developed with time, through evolution, as some variants gain popularity among readers and are canonized by them, while others do not. The secondary goal of the presented paper is also to present the evolution of the canon Star Wars glossaries in German, Polish, and Russian that can be observed through the analyzed material.

\subsection{Jedi}

In Star Wars (1977: 00:33:57), Obi-Wan Kenobi explains to Luke Skywalker that "the JEDI KNIGHTS were the guardians of peace and justice in the Old Republic.” They seemed to possess supernatural powers thanks to their ability to tap into and manipulate the power of the Force, "an energy field created by all living things." The greatest of the Jedi, such as Yoda, were presented with an honorific of a JEDI MASTER.

The word JEDI is one of the most commonly associated with Star Wars. Its conclusive etymology is still unknown though. The most popular explanation states, that it comes from Japanese term jidai geki, the name for samurai films ${ }^{10}$ - a genre which Lucas held in highest admiration. ${ }^{11}$ Another theory posits that JEDI hails from the Barsoom pulp fiction series by Edgar Rice Burroughs, where lords bear the title Jed or Jeddak. Frank Allnutt, on the other hand, suggested a religious interpretation, in which JEDI is a contraction of "JEsus DIsciple" (Porter 2006: 99).

It is worth adding from a linguistic point of view, that JEDI, similarly to the word samurai in English, is an invariable noun. ${ }^{12}$ In early Star Wars materials form JEDIS can be seen nevertheless. ${ }^{13}$ In the past, when referring to the JEDI as a group, authors would rather write JEDI KNIGHTS or the JEDI ORDER, but with time JEDI gained also a collective meaning. ${ }^{14}$ 
Table 1. JEDI in translation

\begin{tabular}{|c|c|c|}
\hline German & Polish & Russian \\
\hline der Jedi & Jedi & Джедай \\
\hline
\end{tabular}

As we see in the table above, the name JEDI did not provide much difficulties to translators. They also proved to be perfectly consequent as during my research I did not encounter any other variants than the ones presented.

In German, JEDI was transferred with a proper article added (der for singular male and die for plural). ${ }^{15}$ The word is written with a capital letter, but this fact is not indicative of anything unusual, since according to German orthography all nouns are written thusly.

Polish translators also used the strategy of transference. Despite the inflectional nature of the Polish language JEDI stayed an indeclinable noun. From a perspective of a Polish speaker, this, alongside the unusual pronunciation, results in the word being perceived as exotic and foreign. Additionally, the capital letter helps to signify its importance.

Russian translators, on the other hand, transcribed the word to the Russian alphabet. They successfully preserved the pronunciation as close as possible to the original. ${ }^{16}$ This also allowed ДЖЕДАЙ to be a declinable word, similarly to a noun like музей (museum), to have a proper plural form - ДЖЕДАИ, and even create a derivative word - an adjective ДЖЕДАЙСКИЙ.

\subsection{Jedi Master}

Translations of the title of a JEDI MASTER offer more variety. It is understandable, since outside of the Star Wars lore this title does not exist. To be properly translated it has to be handled in the context of SWEU. Especially since the common noun master, as presented by the Dictionary of Contemporary English (Summers 2005: 1012), has at least eleven meanings, but only some of them apply to JEDI MASTERS. Those include "someone who is very skilled at something", "a man of authority" and "a teacher."

Table 2. JEDI MASTER in translation

\begin{tabular}{|c|c|c|}
\hline German & Polish & Russian \\
\hline der Jedi-Meister & Mistrz Jedi & Учитель Джедаев \\
& & Властелин Джедаев \\
\hline
\end{tabular}




\begin{tabular}{|l|l|c|}
\hline & & Мастер Джедай \\
\hline
\end{tabular}

When dealing with this honorific, both German and Polish translators decided to use the strategy of substitution. As it is presented in the table above, the word JEDI remained and the word MASTER was replaced with a translation. All German translators consequently used the noun der Meister, which is a good equivalent as - in accordance with PONS Großes Schulwörterbuch Deutsch (Buschner et al. 2001: 705) - it refers to "someone very skilled" but also "an expert craftsman", "a great artist", "a champion."

As for Polish translators, they found a very good equivalent in the noun mistrz, which implies such meanings as "someone evidently more skilled in something than the others", "someone worth looking up to", "a teacher" (Zgółkowa 1998: 310-311). All of these characteristics perfectly describe such iconic characters, who were JEDI MASTERS, as Yoda or Obi-Wan Kenobi.

Russian translators, on the other hand, transcribed the word JEDI and substituted the noun master. However, unlike their German and Polish counterparts, they proposed more than one equivalent. The seemingly most obvious translation, МАСТЕР ДЖЕДАЙ, can be found in 34\% of the analyzed novels, in which the title JEDI MASTER appears (which is $70 \%$ overall). It is the least popular variant most likely because in Russian the noun мacmep is usually associated with crafts and technical work. It is defined by the Толковый словарь русского языка (Ожегов, Шведова 2007: 344) as “a skilled worker", “а specialist in a line of work”, or “а head of a craft guild." Only the fourth and last meaning given by the dictionary defines мacmep as "someone who can do something well." Possibly this is why most translators (it was used in $56 \%$ of the analyzed novels) proposed such translation as УЧИТЕЛЬ ДЖЕДАЕВ (Teacher of Jedi). Noun учитель (Ожегов, Шведова 2007: 846) is a word that exclusively means "someone who shares knowledge." It can be used though to describe both someone simply working in a school and a role model, "a teacher of life." 17 The plural form of genitive of ДЖЕДАЙ implies that the main function of a character bearing this title is to educate and mentor other JEDI, which in a narrow sense is true.

In my opinion, УчИТЕЛЬ ДЖЕДАЕВ is a superior translation to МАСТЕР ДЖЕДАЙ. Still I find the latter acceptable, unlike the third variant, ВЛАСТЕЛИН ДЖЕДАЕВ (Master / Lord of Jedi), which is wrong. The archaic and exalted noun властелин describes "someone who has power and authority.” (Ожегов, Шведова 2007: 86) It can be used as a synonym to master in very specific cases, but not specifically when dealing with characters like Yoda. Especially when властелин is paired with the plural form of genitive of ДжЕДАЙ, which implies that the 
bearer of this title holds power over other JЕDI. ВЛАСТЕЛИН ДЖЕДАЕВ is an older and rather rare variant, which appears only in some of the unlicensed editions of SWEU novels from the early 1990s. Fairly so, as it contradicts what JEDI MASTER stands for in the Star Wars lore.

Interestingly, in novels that were beyond the scope of presented analysis, as they were published after the year 1999, a fourth translation of the honorific was proposed, which in my opinion is the superior one overall: МАГИСТР ДЖЕДАЙ. The word магистр in Russian sounds dignified and is associated with academia, teaching but also an order of knighthood (similarly to English master, German der Meister and Polish mistrz, but not Russian мастер, учитель or властелин). Currently among Russian Star Wars fans the most commonly used variant is namely МАГИСТР ДЖЕДАЙ. It is understandable as it was endorsed by the translators working in the field of audiovisual translation, whose work resonates among larger audience than SWEU novels. The aforementioned variant is featured on Russian DVD and Blu-ray editions of the Prequel Trilogy (1999-2005) and is being used in the theatrical dubbed versions of the ongoing Sequel Trilogy (2015-...).

\subsection{Dark Lord}

In the George Lucas' screenplay of Star Wars, Darth Vader, the main antagonist of the Original Trilogy, is introduced thusly:

The awesome, seven-foot-tall DARK LORD OF THE SITH makes his way into the blinding light of the main passageway. This is Darth Vader, right hand of the Emperor. His face is obscured by his flowing black robes and grotesque breath mask, which stands out next to the fascist white armored suits of the Imperial stormtroopers. Everyone instinctively backs away from the imposing warrior and a deathly quiet sweeps through the Rebel troops. Several of the Rebel troops break and run in a frenzied panic.

(Lucas 1976: 18)

In the novels, he is often referred to either with the full title, or simply as the DARK LORD. With time, SWEU introduced other DARK LORDS to the lore and also explained the honorific's origin and meaning ${ }^{18}$.

Chris Taylor (2015: 160) suggests that while writing the first drafts of the screenplay for Star Wars, Lucas was most likely under the influence of J.R.R. Tolkien's Lord of the Rings trilogy. In fact, Sauron, the main antagonist of that story, is referred to as the DARK LORD and LORD OF MORDOR, which can explain the origins of Darth Vader's honorific (especially since 
all other Dark Lords of fantasy literature, who at one point became the genre's cliché, can also be traced back to Tolkien). ${ }^{19}$

Since Darth Vader's title of the DARK LORD is a reference to another literary work, its translations should also allude to the writings of Tolkien, in order to preserve the connotation: CZARny WŁadCA (Polish translation by Maria Skibniewska, 1961), der DunkLE HerRscher or der DunKLE HeRR (German translation by Margaret Carroux, 1969), ЧЁРНЫЙ ВЛАСТЕЛИН (Russian translation by Vladimir Muravyov and Andrey Kistyakovsky, 1982). None of the translators of the analyzed novels decided to follow this trail. Although, it was not necessarily an incorrect choice. The aforementioned honorifics describe Sauron as the evil (dark) ruler of Mordor, which does not correspond to the character of Darth Vader. This divide stems from the fact that the English noun lord refers to both "a man who has a rank in aristocracy" and "a man in medieval Europe who was very powerful and owned a lot of land" (Summers 2005: 959). In case of Darth Vader, unlike Sauron, the title indicated his position of authority, being "the right hand of the Emperor", but not ruling over people or a land.

Table 3. DARK LORD in translation

\begin{tabular}{|c|c|c|}
\hline German & Polish & Russian \\
\hline \multirow{3}{*}{ der Dunkle Lord } & Czarny Lord & Чёрный Лорд \\
der Schwarze Lord & Mroczny Lord & Тёмный Владыка \\
& Pan Ciemności & Тёмный Лорд \\
& Ciemny Władca & Тёмный Повелитель \\
\hline
\end{tabular}

As it is indicated in the table above, German translators used the strategy of substitution when facing this particular proper name. They consequently used the noun der Lord, which in German is a loanword and associates primarily with British noblemen (Buschner et al. 2001: 676). The purely German word der Herr (lord, owner, proprietor) would be a perfect equivalent had the translators decided to domesticize Darth Vader's title. However, they found the strategy of foreignization more suitable for a space fantasy series, which takes place "a long time ago in a galaxy far, far away." It is arguably a reasonable approach as it furthers the exoticness of the constructed world.

In $90 \%$ of the analyzed novels, the adjective dark in the DARK LORD was translated to German as dunkel, which is arguably the closest possible equivalent. However, few of the earliest translations (by Tony Westermayr) for a reason unclear feature the word schwarz (black) instead. In English, dark and black are close in meaning, as are dunkel and schwarz in 
German. Both pairs of adjectives can be used as synonyms in very specific situations, but understanding the reasoning behind this choice of words provides some difficulty. Possibly, the translator was influenced too strongly by the visual aspect of Star Wars and understood Darth Vader's honorific too literally, as the character is in fact an imposing figure dressed completely in black. His design is clearly symbolic since in many cultures black is the color associated with evil, fear, and death (Kopaliński 2017: 47-48). It can be argued that der SCHWARZE LORD (the Black Lord) is the more sensual variant than der DUNKLE LORD (the Dark Lord), one that influences the reader's imagination more easily, but its obviousness and possible literalness (absent in the original) is what eventually makes it the lesser one.

Polish translators also used the strategy of substitution and decided to transfer the word lord, which in Polish, as well as in German, is a loanword that refers exclusively to the British culture (Zgółkowa 1998: 299). Interestingly enough, a majority of them decided to translate the adjective dark as czarny (black), which creates the same predicament as the one already discussed.

Magdalena Ostrowska, in her translation of Vonda N. McIntyre's The Crystal Star (1996), proposed an entirely different and a rather interesting variant - PAN CIEMNOŚCI (Lord of Darkness). In present Polish, pan is a common title, which equals to $M r$. in English. In this instance, the noun is ingeniously used in archaic fashion, as it refers, similarly as English lord, to "a person of authority or high position in society" and also "a ruler of someone or something." (Zgółkowa 2000: 302-305) The word ciemność (darkness), on the other hand, is a noun that refers to "absence of light" (Zgółkowa 1996: 204) and implies "mystery and wickedness." When these words are placed together, the result is rather unfortunate. Reason for that being, in this case using a noun instead of an adjective, moreover a noun in a genitive form, implies that the individual described as PAN CIEMNOŚCI holds literal "reign over darkness." Such portrayal is overly maleficent when speaking of Darth Vader. Moreover, this connotation has a religious undertone. In fact, for someone who grew up in Polish culture, PAN CIEMNOŚCI does strongly evoke Satan (similarly to Lord of Darkness in English), which was not intended by George Lucas.

Another quite unfortunate variant is featured in Foster's Splinter of the Mind's Eye (1996) translation by Wacław Najdel - CIEMNY WŁADCA. The noun władca (ruler) would be a good equivalent to English lord, although it strongly implies "rulership over someone or something" (Zgółkowa 2004: 441) and not necessarily a high position in the hierarchy, which was the case of Darth Vader and other DARK LORDS. ${ }^{20}$ However, it is the adjective ciemny (dark) that proves to be more problematic. Praktyczny słownik wspótczesnej polszczyzny lists an impressive 
number of ten different meanings of ciemny, but when describing a person, ones that are first to come to mind are either "suspicious, criminal" or "ignorant, unintelligent." (Zgółkowa 1996: 205-205) ${ }^{21}$ Needless to say, CIEMNY WŁADCA is a rather unsuccessful translation.

Steve Perry's Shadows of the Empire (1998) translated by Jarosław Kotarski features a different variant, MroCZNY LORD, which seems to be the closest one to the original. The adjective mroczny (dark) does in fact mean "one that strikes fear and terror" (Zgółkowa 1999: 80) and implies "wickedness and evil." Even though before the year 2000 MROCZNY LORD appears in only one novel, eventually this translation was canonized by the Polish fandom and nowadays it is used predominantly.

When translating the DARK LORD, Russian translators firstly applied the strategy of transcription, and then either substitution or translation. A majority of them kept the loanword лорд (lord), understood as “a high English noble title.” (Ожегов, Шведова 2007: 333) Similarly to their Polish counterparts, most of them translated the adjective dark as чёрныıй (black). However, even though popular Толковый словарь русского языка (Ожегов, Шведова 2007: 884) lists eleven highly diverse definitions of the word (including such as "criminal", "poor," and "unqualified"), arguably the only one that fits the character of Darth Vader refers to the color of his suit. The less popular choice of an adjective, in my opinion more suitable one, was тёмныци (dark). It appears in $42 \%$ of the analyzed novels that mention a DARK LORD. It is a better option, as ТЁМНЫЙ ЛОРД does fit a character, who is a sinister and dreadful person holding a high position in the Imperial hierarchy.

Russian translators offered more diversity when it comes to finding equivalents to lord. In $37 \%$ of the analyzed novels that mention a DARK LORD, variant ТЁМНЫЙ ВЛАДЫКА is featured. The noun владык $а$ is a sublime and archaic word, which refers to a person, who "rules someone or something", but it is also a "title reserved to an archbishop" (Ожегов, Шведова 2007: 86). Similarly to German der Herr and Polish pan, this translation would have been somewhat accurate, had the translators decided to use the strategy of domestication. Additionally, Splinter of the Mind's Eye (1993) translated by Е. Gladkova features a variant ТЁмНЫЙ ПОвЕЛИТЕЛЬ, which is similar in nature. The noun повелитель (ruler) is a synonym to владькка, however it is not qualified as archaic and is devoid of religious undertone. Neither of these two variants is suitable as instead of position of authority, both imply, first and foremost, ownership of a land and a presence of subjects.

Interestingly, out of four proposed Russian translations of a DARK LORD, the two least popular in SWEU novels before the year 2000, ТЁМНЫЙ ЛОРД and ТЁМНЫЙ ПОВЕЛИТЕЛЬ, are the ones that are currently used most among the Russian Star Wars fandom, despite the fact 
that Тёмный Владыка was applied in the dubbed versions of the Prequel Trilogy as featured on Russian DVD and Blu-ray editions of the movies.

\subsection{Dark Lord of the Sith}

As already mentioned, Darth Vader's full title was the DARK LORD OF THE SITH, although before the 2000s it was rarely used outside the promotional materials. This situation had both its internal and external explanation. Internal (i.e. in the Star Wars lore) being that Vader's identity as a SITH was a well-kept mystery. External, since for a long period of time it was unclear to whom or what the SITH refers to: a land, a planet, a group, or a species. ${ }^{22}$ Although Lucas' earliest drafts of the screenplay for Star Wars explained that the SITH were the enemies of the JEDI, an order of followers of the Dark Side of the Force, this fact was made clear as late as in Kevin J. Anderson's Dark Apprentice (1994) and later even more in the Prequel Trilogy, which introduced the name to a wider audience. Its etymology is, however, still unclear.

Table 4. DARK LORD OF THE SITH in translation

\begin{tabular}{|c|c|c|}
\hline German & Polish & Russian \\
\hline \multirow{3}{*}{ der Schwarze Lord der Sith } & Czarny Lord Sithów & \\
& Czarny Lord Sith & Чёрный Лорд Сита \\
der Dunkle Lord der Sith & Mroczny Lord Sith & Чёрный Лорд Ситов \\
& Pan Ciemności Sith & Темный Владыка Сита \\
& Ciemny Władca z Sith & Темный повелитель Сита \\
& Czarny Lord z Sith & \\
\hline
\end{tabular}

Because of its ambiguity, the honorific proved to be problematic for the translators with the exception of German translators. With English and German being a part of the same, West Germanic language family, the task was rather easy. Thanks to the inherent grammatical similarities of these languages, German translators did not need to decipher the meaning of SITH. They simply used the noun in a genitive form, which implies possessiveness, the result being der SchwARZE LORD DER SiTH or DER DUNKLE LORD DER SiTH. They are as enigmatic as the original version, which is of value in this case.

The inflectional nature of Polish language requires an interpretation of what SITH is. The most popular variant, CZARNY LORD SITHÓw, puts the noun in a plural form of genitive. The suffix -ów implies that the SITH are in fact a group of some sort, over which the DARK LORD has authority. Less frequent variant, MROCZNY LORD SITH, incorporates the word as an 
invariable noun. Already exotic looking as it is, the invariability of SITH adds to it an additional level of foreignness and even mysteriousness. It was clearly applied to resemble the use of JEDI in MISTRZ JEDI and this factor possibly helped it to become the predominantly used variant. Additionally, only two translations, proposed by Wacław Najdel (Foster's Spotkanie na Mimban, 1996) and Andrzej Syrzycki (Dave Wolverton's Ślub księżniczki Lei, 1995) ${ }^{23}$, use a preposition $z$ - CIEMNY WŁADCA Z SiTH and CZARNy LORD Z SiTH. This preposition indicates that SITH is rather a place of origin - a land or a planet.

Russian translators, as usual, faced a double task. Firstly, they needed to transfer the artificial neologism into a different alphabet. All of them decided to apply the strategy of transcription. The $/ \theta$ / phoneme is troublesome though as it is not native to the Russian language. Most frequently it is transcribed using the letter $m$ (ex. Smith - Cмum). Unfortunately in this case the result, Сит, happens to be rather inconvenient and unintentionally humorous since it is also a plural genitive form of a common noun cumo (sieve). One might argue that not transcription, but transliteration would have been a more suitable strategy as СИТХ looks and sounds alien to native Russian speakers, and does not associate with any common Russian noun, especially a kitchen tool. ${ }^{24}$

As for the second task, Russian translators, similarly to their Polish counterparts, also needed to interpret what the Sітн is. In all variants the noun Сит was put in a plural form of genitive but the applied suffixes vary. The predominant variant, ЧЁРНЫЙ ЛОРД СИТА, features the $-a$ suffix, which implies that СИт is a place - possibly a land or a planet. However, the ЧЁРнЫЙ ЛОРД СИтОв variant uses the -ов suffix, which (similarly to Polish -ów) suggests that Сит are rather a group.

\section{Conclusion}

The presented analysis of translation of selected proper names to German, Polish, and Russian allows readers to draw several conclusions. Firstly, German and Polish translators used the strategy of transference, when dealing with JEDI and SITH, while Russians applied transcription. When facing longer proper names, honorifics (JEDI MASTER, DARK LORD OF THE SITH), they used either substitution or translation. Secondly, German translators proved to be highly consistent as they rarely offered more than one variant of translation. Most proper names proposed in late 1970s and early 1980s became canonical almost immediately. Polish translators, on the other hand, kept searching for the most suitable translations during the 1990s, offering several different variants as the process continued. However, most canonical versions 
were established before the 2000s. The fact that almost all novels were released by the same publishing house was helpful. Russian translators offered the most versatility, as most of them did not work on more than one SWEU novel and a large number of books were released without license from Lucasfilm. Supposedly this initial chaos is the reason why many Star Wars proper names until this very day do not have their Russian canonical translation.

\section{Appendix}

List of unlicensed Star Wars novels published in Russian in the early 1990s, which I was able to acquire and analyze for this paper:

- Star Wars: From the Adventures of Luke Skywalker. All but the Amalteya edition name George Lucas as the author of the novel instead of Alan Dean Foster. The Entalpiya and Looming ones go as far as calling Lucas "the famous American science fiction writer." Only the Kult-Inform-Press, Balausa, and Kalita releases acknowledge that the novel is based on a movie. A. Snezhko and I. Feygin are the only known translators.

Лукас, Джордж [Lucas, George] ([1976] 1992) „Звездные войны”. [In:] Джордж Лукас [George Lucas], Звездная война. (No indication of a translator). Tula: [publisher unnamed]; 5-203 25 .

Лукас, Джордж [Lucas, George] ([1976] 1992) „Звезда смерти (пятый эпизод)”. [In:] Джордж Лукас [George Lucas], Bторые звездные войны. Translated by: А. Снежко [A.. Snezhko. Tallinn: Лооминг; 3-15826.

Лукас, Джордж [Lucas, George] ([1976] 1992) „Звездные войны”. [In:] Джордж Лукас [George Lucas], Звездные войныл. [No indication of a translator]. Voronezh: Сириус; 3205.

Лукас, Джордж [Lucas, George] ([1992] 1976) Звездные войны. [No indication of a translator]. Saint Petersburg: Saint Petersburg: Культ-информ-пресс.

Лукас, Джордж [Lucas, George] ([1976] 1992),„Звездные войны”. [In:] Джордж Лукас [Lucas, George], Звездные войны. [No indication of a translator]. Alma-Ata: Балауса; 4195.

Лукас, Джордж [Lucas, George] ([1976] 1992) „Звездные войны”. [In:] Джордж Лукас [George Lucas], Звездные войныл. [No indication of a translator]. Moscow: Энтальпия; $3-172$. 
Лукас, Джордж [Lucas, George] ([1976] 1992) „Звездные войны”. [In:] Джордж Лукас [George Lucas], Звездные войны. [No indication of a translator]. Moscow: Калита; 3232.

Лукас, Джордж [Lucas, George] ([1976] 1993) „Звездные войны”. [In:] Джордж Лукас [George Lucas], Звездные войны. (Translated by И. Фейгин [I. Feygin]). Minsk: Сказ; $3-178$.

Фостер, Алан Дин [Foster, Alan Dean] ([1976] 1993) „Звездные войны”. [In:] Алан Дин Фостер [Alan Dean Foster], Звездные войныл. [No indication of a translator]. Moscow: Амальтея; 5-208.

- The Empire Strikes Back. All but the Amalteya issue mistakenly name George Lucas as the sole author or co-author of the novel alongside with Donald Glut. Amalteya, on the other hand, gives the authorship to Alan Dean Foster. The Entalpiya and Looming releases go as far as calling Lucas "the famous American science fiction writer". Only the Balausa and Kalita versions acknowledges that the novel is based on a movie. A. Snezhko and I. Feygin are the only known translators.

Лукас, Джордж [Lucas, George] ([1980] 1992) „Империя наносит ответный удар”. [In: ] Джордж Лукас [George Lucas], Звездная война. [No indication of a translator]. Tula: [publisher unnamed]; 207-34927.

Лукас, Джордж [Lucas, George] ([1980] 1992) „Империя наносит ответный удар (шестой эпизод)”. [In:] Джордж Лукас [George Lucas], Bторые звездные войныл. (Translated by А. Снежко [A. Snezhko]). Tallinn: Лооминг; 159-272 28.

Лукас, Джордж, Гладт, Дональд [Lucas, George, Donald Glut] ([1980] 1992) „Империя наносит ответный удар". [In:] Джордж Лукас [George Lucas], Звездные войны. [No indication of a translator]. Voronezh: Сириус; 207-356.

Лукас, Джордж, Гладт, Дональд [Lucas, George, Glut, Donald] ([1980] 1992) „Империя наносит ответный удар”. [In:] Джордж Лукас [George Lucas], Звездные войныл. [No indication of a translator]. Alma-Ata: Балауса; 197-337.

Лукас, Джордж [Lucas, George] ([1980] 1992) „Империя наносит ответный удар”. [In:] Джордж Лукас [George Lucas], Звездные войныл. [No indication of a translator]. Moscow: Энтальпия; 173-298. 
Лукас, Джордж, Гладт, Дональд [Lucas, George, Glut, Donald] ([1980] 1992) „Империя наносит ответный удар". [In:] Джордж Лукас [George Lucas], Звездные войны. [No indication of a translator]. Moscow: Калита; 233-398.

Лукас, Джордж [Lucas, George] ([1980] 1993) „Империя наносит ответный удар”. [In:] Джордж Лукас [George Lucas], Звездныле войныл. Translated by И. Фейгин [I. Feygin] Minsk: Сказ; 179-298.

Фостер, Алан Дин [Foster, Alan Dean] ([1980] 1993) „Империя наносит ответный удар”. [In:] Алан Дин Фостер, Звездные войнь [No indication of a translator]. Moscow: Амальтея; 209-356.

- Return of the Jedi. The Kalita edition is the only one that features the novel in its entirety. Others were immensely shortened in size. This factis not stated anywhere on the covers. All but the Amalteya edition mistakenly name George Lucas as the author of the novel instead of James Kahn, whose name is never mentioned. Amalteya, on the other hand, gives the authorship to Alan Dean Foster. The Entalpiya and Looming issues go as far as calling Lucas "the famous American science fiction writer." A. Snezhko and I. Feygin are the only known translators. The Kalita edition was allegedly translated by a group of students of Moscow State University.

Лукас, Джордж [Lucas, George] ([1983] 1992) „Возвращение Джедая”. [In:] Джордж Лукас [George Lucas], Звездная война. [No indication of a translator]. Tula: [publisher unnamed]; 353-390²9.

Лукас, Джордж [Lucas, George] ([1983] 1992),„Империя наносит ответный удар (седьмой эпизод)”. [In:] Джордж Лукас [George Lucas], Bmорые звездные войны. (Translated by А. Снежко [A. Snezhko]). Tallinn: Лооминг; 273-302 $2^{30}$.

Лукас, Джордж [Lucas, George] ([1983] 1992) „Возвращение Джедая”. [In:] Джордж Лукас [George Lucas], Звезднье войны. [No indication of a translator]. Voronezh: Сириус; 359-397.

Лукас, Джордж [Lucas, George] ([1983] 1992) „Возвращение Джедая”. [In:] Джордж Лукас [George Lucas], Звездные войны. [No indication of a translator]. Alma-Ata: Балауса; 339-376.

Лукас, Джордж [Lucas, George] ([1983] 1992) „Возвращение Джедая”. [In:] Джордж Лукас [George Lucas], Звездные войны. [No indication of a translator]. Moscow: Энтальпия; 299-335. 
Лукас, Джордж [Lucas, George] ([1980] 1992) „Возвращение Джедая”. [In:] Джордж Лукас [George Lucas], Звездные войны II. [No indication of a translator]. Moscow: Калита; 3-188 31 .

Лукас, Джордж [Lucas, George] ([1983] 1993) „Возвращение Джедая”. [In:] Джордж Лукас [George Lucas], Звездныле войныл. (Translated by И. Фейгин [I. Feygin]). Minsk: Сказ; 299-333.

Фостер, Алан Дин [Foster, Alan Dean] ([1983] 1993) „Возвращение Джедая”. [In:] Алан Дин Фостер [Alan Dean Foster], Звездные войны. [No indication of a translator]. Moscow: Амальтея; 357-398.

\section{Acknowledgements}

Ken NAPZOK, JoSEPH SCRIMSHAW and JENNIFER LANDA of the ForceCenter Podcast Feed - some of the brightest, humorous, and most insightful members of the Star Wars online community. For sharing their creativity and positivity.

IGOR Kotsyuba (ITMO University of Saint Petersburg, Russia) and ANASTASIYA IBAtUllina (Ural State Pedagogical University of Yekaterinburg, Russia) - for their help in acquiring some of the materials used in the presented paper.

VIKTORIYA BERSENEVA (Ural State Pedagogical University of Yekaterinburg, Russia) for being the first reader of the presented paper.

KEITH RICHARDS (East Carolina University, USA) - for additional language assistance.

\section{Notes}

${ }^{1}$ Such a transgression is arguably one of the biggest flaws of The Matrix Revolutions (2003). The first movie (The Matrix, 1999) established a believable dystopian world overrun by robots, which keep humans trapped in a suspended virtual reality in order to use them undisturbed as living batteries. However, a group of freedom fighters, who escaped the imprisonment, lead their campaign against the machines. They are able to manipulate the virtual world in order to obtain there almost godlike powers, while in reality they remain mere humans. Yet, the aforementioned third movie includes a scene in which Neo, the main protagonist, deactivates attacking robots using the power of his will, despite this event taking place in the real world, and lacking any explanation. Such unexpected and unwarranted turn caused viewers to uproar, as the movie suddenly "made no sense".

2 The obvious influence of Lucas' "Used Universe" aesthetic can be observed already in Ridley Scott's Alien (1979), which is another cross-genre classic.

${ }^{3}$ Even though Splinter of the Mind's Eye was the first material released outside of the movies, it is fair to say that what truly formalized the Expanded Universe was the critically acclaimed so-called "Thrawn trilogy" (1991-1993) by Timothy Zahn - a series of sequel novels to the original films.

${ }^{4}$ Complete chronological list of SWEU novels, as they were published in German, can be found here: www.jedipedia.net/wiki/Liste_der_Romane

${ }_{5}^{5}$ Mostly complete chronological list of SWEU novels, as they were published in Polish by Amber, can be found here: http://ossus.pl/biblioteka/Amber.

${ }^{6}$ Barbara Hambly's Dzieci Jedi (1997) was co-translated by Syrzycki and Kotarski. 


\begin{abstract}
${ }^{7}$ For the complete list of unlicensed Star Wars novels I was able to acquire, see the Appendix.
${ }^{8}$ Complete chronological list of SWEU novels, as they were published by Azbooka, can be found here: http://ru.starwars.wikia.com/wiki/\%D0\%90\%D0\%B7\%D0\%B1\%D1\%83\%D0\%BA\%D0\%B0

${ }^{9}$ This situation changed when leading Russian publishing house Eksmo acquired rights from Lucasfilm and started releasing SWEU novels (69 between 2000-2010). They were often handled by the same staff of translators, most noticeably Yana Ashmarina who translated or co-translated 24 of them.

${ }^{10}$ It should be stated that jidai geki literally means "period drama."

${ }^{11}$ Lucas' fascination with samurai films, especially The Hidden Fortress by Akira Kurosawa, is a wellknown fact. See for example Young (2012).

12 This fact gained a lot of attention among the Star Wars community in 2017, when it was revealed, that the eight movie in the Saga will be called The Last Jedi. Soon after translations of the title were announced and it was noticed, that in some languages, which use plural articles, like French, JEDI was clearly used in plural form (ex. Les Derniers Jedi), while in others it was used in singular. Later in year writer and director Rian Johnson
\end{abstract} explained, that the title refers singularly to Luke Skywalker.

${ }^{13}$ See ex. Weinberg (1980: 65)

${ }^{14}$ In the presented paper I will not be discussing the name JEDI KNIGHT as it fails to provide almost any material for analysis. German, Polish and Russian translators universally substituted the noun knight with proper equivalents: DER JEDI-RITTER, RYCERZ JEDI and РЫЦАРЬ ДЖЕДАЙ. Analyzed novels offer no diversity in this matter. However, it is worth mentioning that some German translators (ex. Horst Pukallus in Barbara Hambly's Children of the Jedi, 1995), when the story required it, created a feminine form of the proper name (non-existent in the English original) by changing the article to die and adding suffix -in: DIE JEDI-RITTERIN (Jedi Knightess).

${ }^{15}$ It is worth adding though that in German JEDI is usually pronounced as ['yedi] - in accordance with German phonetic system.

${ }^{16}$ What was beyond the reach of the literary translators, was the word stress, which in Russian is never marked on paper (except for teaching materials for beginners). While in English the first syllable of JEDI is stressed, for a reason unclear in Russian it is the latter one and it has been since the Soviet premiere of Irvin Kershner's The Empire Strikes Back in 1988 (which was the first movie of the Saga to be shown in the USSR).

${ }^{17}$ It is worth mentioning that the dubbed version of The Empire Strikes Back ordered by Channel One Russia features an additional translation of the analyzed proper name - НАСТАВНИК ДЖЕДАЕВ. It represents a similar way of thinking as observed in УЧИТЕЛЬ ДЖЕДАЕВ. The noun наставник also means "a person who educates and disciplines" (Ожегов, Шведова 2007: 394) but is more profound than учитель, as it strongly associates with mentorship and spiritual life.

${ }^{18}$ It was most significantly done by Drew Karpyshyn in his so-called "Darth Bane trilogy" (2006-2009), which was a subject of my earlier work: (Nowakowski 2015).

${ }^{19}$ For discussion on deeper meaning of Dark Lords in fantasy, see Indick (2012: 91-97).

${ }^{20}$ Interestingly, while in the English original also female characters held the title of the DARK LORD, in Polish translations they were changed to DARK LADY. Compare "I am Darth Zannah, DARK LORD OF THE SITH and your new Master" (Karpyshyn 2010a: 303), and "Jestem Darth Zannah, CIEMNA LADY SITHÓw i twoja nowa Mistrzyni” (Karpyshyn 2010b: 219).

${ }^{21}$ To be fair, the adjective dark also implies stupidity, but while in English this meaning is qualified as archaic, for Polish ciemny it is still common.

${ }^{22}$ Timothy Zahn, when writing his famed "Thrawn trilogy", proposed to call a species of servants to Darth Vader the SITH thus explaining the meaning of his title. However, the idea was turned down by executives at Lucasfilm. Eventually the species were named Noghri.

${ }^{23}$ Syrzycki uses this variant exclusively in Wolverton's Ślub księżniczki Lei (1995) - the first out of 53 SWEU novels he translated in his life.

${ }^{24}$ In fact, in the 2000s Russian translators introduced a transliterated version of SITH. Currently СИТХ is the canonical Russian translation.

${ }^{25}$ Publisher is unnamed. Title of the compilation translates as Star War.

${ }^{26}$ Title of the novel translates as Death Star. It is mistakenly numbered as Episode V. Title of the compilation translates as Second Star Wars.

${ }^{27}$ Publisher is unnamed. Title of the compilation translates as Star War.

${ }^{28}$ Novel is mistakenly numbered as Episode VI. Title of the compilation translates as Second Star Wars.

${ }^{29}$ Publisher is unnamed. Title of the compilation translates as Star War.

${ }^{30}$ Novel is mistakenly numbered as Episode VII. Title of the compilation translates as Second Star Wars.

${ }^{31}$ Compilation also includes Star Trek: The Wrath of Khan novel by Vonda N. McIntyre (1982). 


\section{Sources}

Anderson, Kevin J. (1994) Dark Apprentice. New York: Bantam Spectra.

Foster, Alan Dean (1978) Splinter of the Mind's Eye. New York: Random House.

Foster, Alan Dean ([1978] 1996) Spotkanie na Mimban [Splinter of the Mind's Eye. New York: Random House]. Translated by Wacław Najdel. Warszawa: Amber.

Hambly, Barbara ([1995] 1996) Palpatines Auge [Children of the Jedi. New York: Bantam Spectra]. Translated by Horst Pukallus. München: Heyne.

Hambly, Barbara ([1995] 1997) Dzieci Jedi [Children of the Jedi. New York: Bantam Spectra].

Translated by Andrzej Syrzycki, Jarosław Kotarski. Warszawa: Amber.

Karpyshyn, Drew (2006) Darth Bane: Path of Destruction. New York: Del Rey.

Karpyshyn, Drew (2007) Darth Bane: Rule of Two. New York: Del Rey.

Karpyshyn, Drew (2010a) Darth Bane: Dynasty of Evil. New York: Del Rey.

Karpyshyn, Drew (2010b) Darth Bane: Dynastia zła [Darth Bane: Dynasty of Evil. New York:

Del Rey]. Translated by Błażej Niedziński. Warszawa: Amber.

Lucas, George ([1976] 1979) "Star Wars: Episode IV - A New Hope. From the Journal of the Whills. Revised Fourth Draft." [In:] Carol Titelman (ed.) The Art of Star Wars. New York: Ballantine Books; 7-137.

Lucas, George (1976) Star Wars: From the Adventures of Luke Skywalker. New York: Ballantine Books.

McIntyre, Vonda N. (1982) Star Trek: The Wrath of Khan. New York: Pocket Books.

McIntyre, Vonda N. ([1994] 1996) Kryształowa gwiazda [The Crystal Star. New York: Bantam

Spectra]. Translated by Magdalena Ostrowska. Warszawa: Amber.

Perry, Steve ([1996] 1998) Cienie Imperium [Shadows of the Empire. New York: Bantam Spectra]. Translated by Jarosław Kotarski. Warszawa: Amber.

Tolkien, J. R. R. ([1954] 1961) Wtadca pierścieni: Wyprawa [Lord of the Rings: The Fellowship of the Ring. Vol. 1. London: George Allen \& Unwin]. Vol. 1. Translated by Maria Skibniewska. Warszawa: Czytelnik.

Tolkien, J. R. R. ([1954] 1969) Herr der Ringe: Die Gefährten [Lord of the Rings: The Fellowship of the Ring. Vol. 1. London: George Allen \& Unwin]. Vol. 1. Translated by Margaret Carroux. Stuttgart: Hobbit Presse im Ernst Klett Verlag. 
Wolverton, Dave ([1994] 1995) Ślub księżniczki Leii [The Courtship of Princess Leia. New York: Bantam Spectra]. Translated by Andrzej Syrzycki. Warszawa: Amber.

Wolverton, Dave ([1999] 1999) Uczeń Jedi: Narodziny Mocy [Jedi Apprentice: The Rising Force. New York: Scholastic]. (Translated by Krystyna Kwiatkowska). Warszawa: Egmont.

Zahn, Timothy (1991) Heir to the Empire. New York: Bantam Spectra.

Zahn, Timothy (1992) Dark Force Rising. New York: Bantam Spectra.

Zahn, Timothy (1993) The Last Command. New York: Bantam Spectra.

Толкиен Дж. Р. Р. [Tolkien, J. R. R.] ([1954] 1982) Хранители [Lord of the Rings: The Fellowship of the Ring. Vol. 1. London: George Allen \& Unwin]. (Translated by B. Муравьев, А. Кистяковский [A. Kistyakovsky, V. Muravyov]). Moscow: Детская литература

Фостер, Алан Дин [Foster, Alan Dean] ([1978] 1993) Осколок ока разума [Splinter of the Mind's Eye. New York: Random House]. (Translated by Е. Гладкова [Е. Gladkoya]). Moscow: Гриф-Ф.

\section{Referenced literature}

Buschner, Adelheid, Hecht, Dörthe, Morsi, Annette, Morsi, Gamal, Schnörch, Ulrich (2001) (eds.) PONS Großes Schulwörterbuch Deutsch. Stuttgart, Düsseldorf, Leipzig: Ernst Klett Verlag.

Indick, William (2013) Ancient Symbology in Fantasy Literature: A Psychological Study. Jefferson: McFarland.

Kopaliński, Władysław (2017) Słownik symboli. Warszawa: Oficyna Wydawnicza RYTM. Newmark, Peter (1988a) A Textbook of Translation. Hertfordshire: Prentice Hall.

Newmark, Peter (1988b) Approaches to Translation. Hertfordshire: Prentice Hall.

Nowakowski, Adam (2015) „Tako rzecze Bane. Nadczłowiek w Drodze zagłady Drew Karpyshyna". [In:] Monika Kocot, Kamil Szafraniec (ed.) Języki (pop)kultury w literaturze, mediach i filmie. Łódź: Wydawnictwo Uniwersytetu Łodzkiego; 53-62.

Poluszyński, Bartosz (2012) „Strategie tłumaczeniowe stosowane podczas przekładu nazw własnych na przykładzie wybranych polsko-angielskich artykułów z Wikipedii - analiza jakościowa i ilościowa”. Języki: obce w szkole, 4; 42-50. 
Porter, Jennifer E. (2006) “«I am a Jedi»: Star Wars Fandom, Religious Belief, and the 2001 Census.” [In:] Matthew Kapell, John Shelton Lawrence (eds.) Finding the Force of the Star Wars Franchise: Fans, Merchandise, \& Critics. New York: Peter Lang; 95-112.

Summers, Della (2005) (ed.) Dictionary of Contemporary English. Harlow: Pearson Education Limited.

Taylor, Chris ([2014] 2015) Gwiezdne Wojny: jak podbiły wszechświat? [How Star Wars Conquered the Universe. New York: Basic Books]. (Translated by Agnieszka BukowczanRzeszut). Kraków: Społeczny Instytutu Wydawniczy Znak.

Weinberg, Larry (1980) Star Wars. The Making of the Movie. New York: Random House.

Zgółkowa, Halina (1996) (ed.) Praktyczny słownik współczesnej polszczyzny. Vol. 7. Poznań: Wydawnictwo Kurpisz.

Zgółkowa, Halina (1998) (ed.) Praktyczny słownik współczesnej polszczyzny. Vol. 19. Poznań: Wydawnictwo Kurpisz.

Zgółkowa, Halina (1999) (ed.) Praktyczny słownik współczesnej polszczyzny. Vol. 22. Poznań: Wydawnictwo Kurpisz.

Zgółkowa, Halina (2000) (ed.) Praktyczny słownik współczesnej polszczyzny. Vol. 27. Poznań: Wydawnictwo Kurpisz.

Zgółkowa, Halina (2004) (ed.) Praktyczny słownik współczesnej polszczyzny. Vol. 45. Poznań: Wydawnictwo Kurpisz.

Ожегов, С. И., Шведова, Н. Ю. [Ozhegov S. I., Shvedova N. Y.] (2007) (eds.) Толковый словарь русского языка. Моscow: А Темп.

\section{Referenced online material}

Landa, Jennifer. (2018, June 29). Happy Beeps - The Sounds of Ben Burtt. ForceCenter Podcast Feed. Audio file retrieved from www.podomatic.com/podcasts/forcecenterpod/episodes/2018-06-29T06_00_00-07_00

List der Romane: Legends-Romane [List of SWEU novels released in German]. Retrieved from www.jedipedia.net/wiki/Liste_der_Romane

Scrimshaw, Joseph, Napzok, Ken. (2018, March 1). Databank Brawl - Episode 92: First Order Snowtrooper vs Vulptex. ForceCenter Podcast Feed. Audio file retrieved from www.podomatic.com/podcasts/forcecenterpod/episodes/2018-03-01T06_00_00-08_00

Wydane pozycje: ksiażki [List of SWEU novels published by Amber]. Retrieved from http://ossus.pl/biblioteka/Amber 
Young, Brian. (2012, September 24). The Cinema Behind Star Wars: The Hidden Fortress [article]. Retrieved from www.starwars.com/news/the-cinema-behind-star-wars-thehidden-fortress

Серия «Звёздныле войныл» [List of SWEU novels published by Azbooka]. Retrieved from http://ru.starwars.wikia.com/wiki/\%D0\%90\%D0\%B7\%D0\%B1\%D1\%83\%D0\%BA\%D0 $\underline{\% \mathrm{~B} 0}$

\section{Referenced motion pictures}

Carroll, Gordon, Giler, David, Hill, Walter (prod.) Scott, Ridley (dir.) (1979) Alien. United States: Twentieth Century Fox.

Kazanjian, Howard (prod.), Marquand, Richard (dir.) (1983) Star Wars: Return of the Jedi. United States: Lucasfilm / Twentieth Century Fox.

Kennedy, Kathleen, Bergman, Ram (prod.), Johnson, Rian (dir.) (2017) Star Wars: The Last Jedi. United States: Lucasfilm / Walt Disney Studios.

Kurtz, Gary (prod.), Lucas, George (dir.) (1977) Star Wars. United States: Lucasfilm / Twentieth Century Fox.

Kurtz, Gary (prod.), Kershner, Irvin (dir.) (1980) Star Wars: The Empire Strikes Back. United States: Lucasfilm / Twentieth Century Fox.

McCallum, Rick (prod.), Lucas, George (dir.) (1999) Star Wars: The Phantom Menace. United States: Lucasfilm / Twentieth Century Fox.

Sanezumi, Fujimoto, Kurosawa, Akira (prod.), Kurosawa, Akira (dir.) (1958) The Hidden Fortress. Japan: Toho.

Silvers, Joel (prod.), Wachowski, Larry, Wachowski, Andy (dir.) (1999) The Matrix. United States: Warner Bros.

Silvers, Joel (prod.), Wachowski, Larry, Wachowski, Andy (dir.) (2003) The Matrix Revolutions. United States: Warner Bros. 